\title{
The European Society for Blood and Marrow Transplantation (EBMT) Consensus Guidelines for the Detection and Treatment of Donor Specific Anti-HLA Antibodies (DSA) in Haploidentical Hematopoietic Cell Transplantation
}

\author{
Stefan O. Ciurea1 ${ }^{1}$ Kai Cao${ }^{1}$, Marcelo Fernadez-Vina², Piyanuch Kongtim ${ }^{3}$, Monzr Al Malki ${ }^{4}$, \\ Ephraim Fuchs $^{5}$, Leo Luznik ${ }^{5}$, Xiao-Jun Huang ${ }^{6}$, Fabio Ciceri ${ }^{7}$, Franco Locatelli ${ }^{8}$, Franco \\ Aversa $^{9}$, Luca Castagna ${ }^{10}$, Andrea Bacigalupo ${ }^{11}$, Massimo Martelli ${ }^{12}$, Didier Blaise ${ }^{13}$, \\ Rupert Handgretinger ${ }^{14}$, Denis-Claude Roy ${ }^{15}$, Paul O’Donnell ${ }^{16}$, Asad Bashey ${ }^{17}$, Hillard M. \\ Lazarus $^{18}$, Karen Ballen ${ }^{19}$, Bipin N. Savani ${ }^{20}$, Mohamad Mohty ${ }^{21}$, Arnon Nagler ${ }^{22}$
}

${ }^{1}$ The University of Texas MD Anderson Cancer Center, Houston, TX, USA, '2Stanford University, Stanford, CA, USA, ${ }^{3}$ Thammasat University, Bangkok, Thailand, ${ }^{4}$ Department of Hematology and HCT, City of Hope National Medical Center, Duarte, CA, USA, ${ }^{5}$ Division of Hematologic Malignancies, Sidney Kimmel Comprehensive Cancer Center at Johns Hopkins, Baltimore, MD, USA, ${ }^{6}$ Institute of Hematology, Peking University People's Hospital, Beijing, China, ${ }^{7}$ Hematology and BMT Unit, San Raffaele Scientific Institute, Milan, Italy, ${ }^{8}$ Department of Pediatric Hematology and Oncology, IRCCS Ospedale Pediatrico Bambino Gesu, Rome, Italy, ${ }^{9} \mathrm{Hematology}$ and BMT Unit, University of Parma, Italy, ${ }^{10}$ Hematology Department, Humanitas Clinical and Research Center, Milan, Italy, ${ }^{11}$ Instituto di Ematologia, Fondazione Policlinico Universitario Gemelli, Universita' Cattolica del Sacro Cuore, Roma, Italia, ${ }^{12}$ University of Perugia, Perugia, Italy,

${ }^{13}$ Departement D'Hematologie, Programme de Transplantation et de Therapie Cellulaire, Centre de Recherche en Cancerologie de Marseille, Institut Paoli Calmettes, Marseille, France, ${ }^{14}$ Department of Hematology and Oncology, Children's University Hospital, Tubingen, Germany, ${ }^{15}$ Blood and Marrow Transplantation Program, Hôpital Maisonneuve-Rosemont, Université de Montréal, Montreal, Quebec, Canada ${ }^{16}$ Massachusetts General Hospital Cancer Center, Boston, MA, USA, ${ }^{17}$ BMT Program at Northside Hospital, Atlanta, GA, USA, ${ }^{18}$ Case Western Reserve University, Cleveland, OH, USA, ${ }^{19}$ University of Virginia Health System, Charlottesville, VA, USA, ${ }^{20}$ Vanderbilt University Medical Center, Nashville, TN, USA, ${ }^{21}$ Hopital Saint-Antoine, Paris, France, ${ }^{22}$ Hematology Division, Chaim Sheba Medical Center, Tel Hashomer, Israel, Acute Leukemia Working Party of the EBMT, Hopital Saint-Antoine, Paris, France.

\footnotetext{
Abstract

Haploidentical donors are now increasingly considered for transplantation in the absence of HLA matched donors or when an urgent transplant is needed. Donor-specific anti-HLA antibodies

Correspondence to: Stefan O. Ciurea, MD, Associate Professor, Department of Stem Cell Transplantation and Cellular Therapy, The University of Texas MD Anderson Cancer Center, 1515 Holcombe Blvd, Unit 423, Houston, TX 77030, Phone: 713-745-0146, Fax: 713-794-4902; sciurea@mdanderson.org.

Conflict of interest: The authors have no competing financial interests to disclose for this work.
} 
(DSA) have been recently recognized as an important barrier against successful engraftment of donor cells, which can affect transplant survival. DSA appear more prevalent in this type of transplant due to higher likelihood of alloimmunization of multiparous females against offspring's HLA antigens, and the degree of mismatch. Here we summarize the evidence for the role of DSA in the development of primary graft failure in haploidentical transplantation and provide consensus recommendations from the European Society for Blood and Marrow Transplant Group on testing, monitoring and treatment of patients with DSA receiving haploidentical hematopoietic progenitor cell transplantation.

\section{Introduction}

Haploidentical donors have been increasingly considered for transplantation in patients without HLA matched donors due to improved transplant outcomes, owing to novel approaches for prevention of graft-versus-host disease (GVHD), primarily to the use of posttransplantation cyclophosphamide (PTCy), but also to other effective methods to control alloreactive reactions in this setting, such as selective alpha-beta T-cell depletion, enhanced GVHD prevention with multiple agents including ATG in the non-T cell depleted haploidentical transplant approach, extracorporeal photodepletion or administration of $\mathrm{T}$ regulatory cells (Tregs) in the T cell depleted haploidentical transplant setting. ${ }^{1-8}$

Primary graft failure (PGF) remains a major and dreadful complication after transplantation associated with very poor outcomes, either due to increased transplant-related mortality following infectious complications or due to early relapse in the absence of a functioning graft. ${ }^{9}$ The incidence of PGF varies widely with the method of $\mathrm{T}$ cell depletion, improved in the modern era due to maintaining T-cells in the graft or partial T-cell depletion, better understanding of the effects of conditioning regimens and application of T-cell therapy as part of the conditioning for transplantation, as well as identification of donor-specific anti HLA antibodies (DSA) as a major cause of PGF in haploidentical hematopoietic cell transplantation (HHCT) and other types of HLA mismatched donor transplants. ${ }^{5,10-19}$

Cellular mediated rejection (primarily caused by residual recipient $\mathrm{T}$ cells) has been historically considered the main cause of PGF in hematopoietic cell transplantation, likely because allogeneic transplants were almost exclusively human leukocyte antigens (HLA) matched transplants. T-cell factors that could favor rejection, like removing T-cells from the graft and non-myeloablative conditioning (lower intensity anti-host T-cells therapy) could explain the higher incidence of PGF in these types of transplants, either HLA matched or mismatched. In haploidentical transplantation, the maximum genetic disparity between the donor and recipient can lead to intense bi-directional alloreactive reactions between the donor and recipient, not only in the graft-versus-host but also in the host-versus-graft direction, which can lead to a higher predisposition for developing PGF in recipients of haploidentical grafts compared with HLA matched donor transplants. ${ }^{20,} 21$ Host natural killer (NK) cells, in addition to T lymphocytes, that survived the conditioning chemotherapy may also be responsible for cellular-mediated immune responses. ${ }^{22,23}$

Other predisposing/causative factors which are known to affect engraftment not only in haploidentical transplants but also in all forms of transplantation are myelosuppressive drugs 
(such as ganciclovir, linezolid, trimethoprim/sulfamethoxazole), viral infections (for example CMV, HHV6) and bacterial sepsis, major ABO incompatibility or stromal defects have been associated with PGF. Myeloablative conditioning (enhanced clearance of recipient $\mathrm{T}$ cells), peripheral blood graft (higher $\mathrm{T}$ cell dose) and a non-T cell depleted graft may also facilitate engraftment. ${ }^{17,24-30}$

A greater understanding of "humoral" rejection by identification of donor specific anti-HLA antibodies as an important cause of PGF in HLA mismatched transplants and especially in haploidentical transplants, has contributed to a greater understanding of causes of PGF in this setting. ${ }^{13,31-33}$ This form of graft rejection is typically caused by recipient preformed antibodies against donor HLA antigens, which may be more important in haploidentical transplants than in other types of HLA mismatched transplants due to the particular setting of allosensitization of the female recipient through pregnancy against paternal HLA antigens shared with a child that could later in life become a potential transplant donor. ${ }^{34}$

In this review, we address the role of DSA in the development of PGF in haploidetical transplantation as well as provide comprehensive recommendations for clinical practice regarding testing using modern methods for detection of HLA antibodies and desensitization strategies for patients with DSAs in order to improve engraftment rate and transplant outcomes in these patients.

\section{How DSA influence outcome of haploidentical stem cell transplantation?}

Antibody-mediated graft rejection has been a well-recognized cause of graft rejection and organ failure in solid organ transplantation. Preformed circulating DSAs can cause hyperacute graft rejection that presents within minutes of revascularization of the transplanted organ whereas antibodies developed post-transplant from pre-transplant antigen exposure is a major cause of chronic or recall graft rejection. ${ }^{35}$ This phenomenon also has been documented in animal models of allogeneic hematopoietic cell transplantation (AHCT), in which preformed antibodies present at the time of marrow infusion presented a major barrier against successful engraftment resulting in rapid graft rejection (within a few hours) in allosensitized recipients of MHC mismatched bone marrow transplantation, while cellularmediated graft rejection takes much longer. ${ }^{32,} 36$ Since the increasing use of partially mismatched hematopoietic stem cell donors such as haploidentical, cord blood and mismatched unrelated donors for treatment of various diseases, antibody-mediated graft rejection has become an important issue in AHCT outcomes.

\section{DSA and primary graft failure/delayed engraftment}

After an initial study in which the MD Anderson cancer Center (MDACC) group found an association between DSA and PGF in haploidentical transplants recipients, ${ }^{13}$ several groups have confirmed this association and a likely causative effect between DSA and the development of PGF in HHCT, ${ }^{34,37,38}$ as well as in hematopoietic stem cell transplantation with other HLA mismatched donors. ${ }^{33,}$, 39-43 
In the largest study to date, the same group reported on 122 consecutively treated haploidentical stem cell transplant recipients and confirmed the clear association between DSA and PGF in this setting in both T cell depleted as well as T cell replete haploidentical transplants. In this study, the incidence of DSA was $18 \%$ (22 of 122 patients) and PGF occurred in $32 \%$ of the patients who developed DSA, while only $4 \%$ of patients without DSAs had primary GF $(\mathrm{P}<0.001)$. In addition, the time to engraftment was significantly delayed in patients with DSAs compared with patients with negative DSAs (19 days vs. 18 days, $\mathrm{p}=0.004){ }^{34}$

In another study by Yoshihara et al., 79 patients receiving HHCT were tested for anti-HLA antibodies, 16 patients (20.2\%) were found to have anti-HLA antibodies, including 11 patients with anti-HLA antibodies direct against donor HLA antigens. The cumulative incidence of donor neutrophil (61.9\% vs. $94.4 \%, P=0.026)$ and platelet engraftment $(28.6 \%$ vs. $79.6 \%, \mathrm{P}=0.035$ ) was significantly lower in DSA-positive than in DSA-negative patients. Moreover, they found that DSA levels $>5,000$ were the only significant risk factor for GF in multivariate analysis $(\mathrm{P}=0.006) .{ }^{37} \mathrm{In}$ a more recent study by Chang and colleagues, this group showed that not only primary GF and delayed engraftment were associated with DSA but also primary poor graft function in patients receiving unmanipulated HHCT. Of the 345 tested cases, 87 (25.2\%) were anti-HLA antibody positive and 39 patients $(11.3 \%)$ had anti-HLA antibodies against donor HLAs. The patients with DSAs $\geq 2,000$ MFI experienced a significantly higher incidence of primary poor graft function than those with a MFI $<2,000(27.3 \%$ vs. $1.9 \%, \mathrm{P}=0.003) .^{38}$

\section{DSA and effect on transplant survival}

As seen in solid organ transplantation, the presence of DSA has been shown to correlate also with survival in recipients of hematopoietic stem cell transplants. PGF is an unfortunate event, which, most of the time, will need an immediate second transplant to recover recipient's hematopoiesis. This is associated with high mortality rate either due to infectious complications or disease relapses in the absence of an effective graft-versus-tumor effect.

Several studies also evaluated the effect of DSA on survival for patients treated with different HLA mismatched donors. ${ }^{13}$, 33, 34, 37-44 With regards to haploidentical transplantation, the MDACC group found that in addition to a higher PGF rate in patients with DSA, there was a significantly worse survival for patients who developed PGF compared with those who did not (5.3 months vs. 17.1 months) (Figure 1). ${ }^{34}$ These results confirm the negative impact not only on engraftment but also on survival seen with other donor types and reemphasize the need to avoid this complication by early detection and treatment of patients with DSA.

In conclusion, DSA are associated with a higher incidence of engraftment failure and poor survival in haploidentical stem cell transplantation. Efforts should be made to screen all patients before transplant, and if possible, select donors with no DSA against, and desensitize patients with DSA prior to transplant to avoid negative outcomes on engraftment and survival. Information on desensitization strategies is presented below in this review. 


\section{Which patients are at risk of developing DSA?}

The human major histocompatibility complex (MHC), also termed the human leukocyte antigen (HLA) complex, consists of more than 200 genes located close together on chromosome $6 .{ }^{45}$ The molecules encoded by genes within this region are of fundamental importance to the innate and antigen-specific immune systems. The high allelic variability represents a barrier in successful transplantation. Exposure to non-self HLA antigen can result in anti-HLA antibody developing in transplant recipients. These anti-HLA antibodies may be unique to a specific allele or limited group or recognize an epitope that is shared by more than one HLA molecules resulting in cross-reactivity.

In adult patients with hematologic malignancies referred for allogeneic hematopoietic cell transplantation, the reported total prevalence of anti-HLA antibodies can be up to $40 \%$, especially in HLA mismatched transplantation. ${ }^{13}$, 33, 37-39, 43, 44 However, not all of these anti-HLA antibodies are directed against donor HLA antigens. With the use of highly sensitive solid-phase immunoassays, DSAs were identified in up to $24 \%$ of AHCT recipients. ${ }^{12,37,39,41-43,46}$ Overall, in HHCT, the prevalence of DSAs may range between $10 \%$ and $21 \%{ }^{13,34,37,38}$ This proportion is highly dependent on the recipient's gender, with very low prevalence in male recipients (5\%) as compared with female recipients (86\%).

${ }^{34}$ In addition to a much higher prevalence of DSA in female patients, much higher DSA levels were identified compared with DSA levels in allosensitized male patients. ${ }^{33}, 34$ AntiHLA antibodies detected in female patients are much more often DSAs in the settings of "child-to-mother" haploidentical transplants than in the setting of mismatched unrelated donor transplants ${ }^{13,40}$ as a result of sensitization during pregnancies by offspring's HLA antigens and this risk is further increased with a higher number of pregnancies with the reported incidence up to $50 \%$ in the female recipient with a history of multiple pregnancies. 47

Besides pregnancy, transfusion of allogeneic blood products also has been identified as a common risk factor for developing anti-HLA antibodies both in healthy individuals and transplant recipients. ${ }^{13,33,48,49}$ Several studies using contemporary solid phase assay methods have confirmed that blood transfusions induce or reactivate HLA alloimmunization in solid organ transplant recipients ${ }^{50-52}$ The risk of transfusion associated HLA alloimmunization is higher in patients receiving leukocyte and platelet transfusion compare to erythrocytes, since these cells express large number of HLA antigens. Although they express lower levels of HLA class I molecules, erythrocyte (red blood cell) transfusions may also increase risk of developing anti-HLA antibodies as large numbers of erythrocytes are transfused to certain groups of patients and HLA allosensitization would be expected to occur. ${ }^{53}$ This is particularly seen in children or young adults with hemoglobinopathies and older individuals with more indolent hematologic malignancies requiring frequent transfusions such as patients with myelodysplastic syndromes or myeloproliferative diseases.

For adults with hematological malignancies, pregnancy appears to be a much more powerful inducer of anti-HLA antibodies and DSA, as multiparous females were found to be much 
more likely to be allosensitized and the median antibody levels in females was found to be much higher compared with allosensitized male recipients. ${ }^{34}$

In conclusion, the development of anti-HLA antibodies may occur in all patients receiving an HLA mismatched donor transplant, particularly in haploidentical transplants, with higher prevalence in multiparous females compared with males. Evaluation of anti-HLA antibodies should therefore be performed in all patients receiving a haploidentical transplant.

\section{How do we identify anti-HLA antibodies in transplant recipients?}

A number of methods have been developed for the screening and specification of anti-HLA antibodies in transplant recipients. Generally, these methods are categorized into cell-based assays or solid-phase immunoassays.

\section{Cell-based assays}

Cell-based assays were first used for donor selection in HLA allosensitized solid organ transplant recipients. ${ }^{54}$ In cell-based crossmatched assays, donor leukocytes are incubated with recipient serum. If the patient serum contains DSA, the antibody will bind its target antigen on the donor lymphocytes causing a positive test. ${ }^{55}$ The lymphocytotoxic test so called complement-dependent cytotoxicity (CDC) test is the oldest cell-based assay used either for the screening of anti-HLA antibodies or donor-specific crossmatches. This method detects complement-activating antibodies lysing lymphocytes. Antibody-antigen interaction leads to fixation of exogenous complement onto target lymphocytes, and results in cell death. Addition of a secondary antibody (anti-human IgG, AHG-CDC) can improve the sensitivity of the CDC test by detecting non-complement fixing antibodies. The positive CDC test can predict hyperacute graft rejection caused by DSA in solid organ transplantations. ${ }^{54,56}$ However, this assay is not very sensitive, requires a relatively large number of viable donor lymphocytes, also can detect non-HLA antibodies, which might not be clinically significant. Importantly, CDC screening cannot distinguish all antibody specificities in highly sensitized patients with complex antibody profiles (Table 1). ${ }^{57}$

The more sensitive method of antibody detection is flow cytometry crossmatch test. This method can detect antibody binding to target lymphocytes using a fluorescent secondary antibody and quantification via a flow cytometer. It can also be used for antibody identification by adding HLA-typed donor lymphocytes. It is more sensitive than the CDC test and has been proven useful in identifying weak DSA, which might cause graft rejection. ${ }^{58}$ However, the drawback of this method is it is difficult to standardize and might detect non-HLA antibodies (Table 1). ${ }^{57}$

\section{Solid-phase immunoassays}

Solid-phase immunoassays (SPI) use solubilized HLA molecules bound to a solid matrix that could either be a microtiter plate (enzyme-linked immunosorbent assay; ELISA) or polystyrene beads (multiplexed multianalyte bead arrays) performed on a conventional flow cytometer or a fluoroanalyzer (Luminex) ${ }^{59-61}$ The comprehensive array of common and many rare HLA alleles for all 11 HLA loci (HLA-A, -B, -C, -DRB1, -DRB3, -DRB4, DRB5, -DQA1, -DQB1, -DPA1, and -DPB1) present in the Luminex SAB array enables the 
precise definition of HLA antibodies contained in complex sera. ${ }^{61,62}$ Beside antibody identification, the SPI can also give a semiquantitative assessment of antibody binding ability as the test results can be expressed as optical density ratios compared with a negative control (ELISA), median channel of fluorescence (flow cytometry), or MFI value (Luminex). The tests are more sensitive than the cell-based assays since it can detect a low level of anti-HLA antibodies in the patient serum. However, the test drawback is that the variable HLA protein density on beads and blocking factors may cause false-negative or misleading low assessment of antibody levels (prozone effect) (Table 1). ${ }^{57}$

\section{Assessment of functionality of HLA antibodies}

Assessment of antibody functions can be done using the modified SPI such as C4d and C1q assays. These tests are enabling to distinguish complement fixing from non-complement fixing antibody. The $\mathrm{C} 4 \mathrm{~d}$ assay requires complement activation to occur. It has been shown in some studies that the presence of $\mathrm{C} 4 \mathrm{~d}$ fixing antibody is associated with low graft survival in various types of solid organ transplant. ${ }^{63,64}$

The C1q testing was also designed to distinguish complement fixing from non-complement fixing antibody but does not require complement activation other than the binding antibody to $\mathrm{C} 1 \mathrm{q} .{ }^{65}$ The test is more sensitive than $\mathrm{C} 4 \mathrm{~d}$ test and also detects more $\mathrm{IgG}$ antibodies as well as complement fixing IgM. The positive $\mathrm{Clq}$ test has been shown to correlate with antibody-mediated graft rejection and survival in kidney and cardiac transplantation. ${ }^{66-68}$ Similar findings have been reported in hematopoietic stem cell transplantation, in which a clear association between high DSA levels and C1q positivity was noted and confirmed a high risk of graft failure with complement-binding DSA $(\mathrm{C} 1 \mathrm{q}+)$ in $\mathrm{HHCT}^{34}$

In conclusion, solid-phase assays are now preferred for detection and monitoring of DSA in hematopoietic stem cell transplantation. In addition, assessment of complement-binding DSA (C1q testing) is needed in patients with DSA as complement-binding DSA expose the recipient to a higher risk of PGF as detailed below. Cell-based assays (flow cytometry crossmatch) are performed in several centers with experience in such testing and may be considered as an adjunct or alternative to solid-phase assays, which are now performed in the majority of transplant centers.

\section{What is the mechanism by which DSA contribute to graft failure in hematopoietic stem cell transplantation?}

The exact mechanisms by which DSA cause graft failure remain to be elucidated. In general, antibody-mediated graft rejection may occur either by antibody-dependent cell-mediated cytotoxicity or complement-mediated cytotoxicity. ${ }^{69}$ Several animal studies as well as studies from solid organ transplantation point towards complement-mediated cytotoxicity. In animal models of AHCT, Xu et al. demonstrated that preformed antibodies presented at the time of marrow infusion in multi-transfused mice were a major barrier against marrow engraftment resulting in rapid graft rejection within a few hours. ${ }^{32}$ Same result was found in a study by Taylor et al., which showed a rapid rejection of donor bone marrow cells in antibody-primed mice and this reaction was dependent on a host $\mathrm{FcR}^{+}$mechanism. ${ }^{36}$ In this 
study, antibody-mediated rejection of a moderate bone marrow dose was nearly complete by 3 hours. ${ }^{36}$

In 1969, Patel and Terasaki described a highly significant correlation between a positive CDC crossmatch and hyperacute or accelerated acute rejection in renal transplant patients. ${ }^{54}$ Also, evidence from studies in cardiac and renal transplant patients has shown that complement system is activated in the transplanted organ during rejection and can be detected by measuring the products of complement activation in the patients' blood, urine as well as in the transplanted organ itself. ${ }^{70-73}$ Collectively, results from several studies have suggested a link between complement-binding antibodies and adverse graft outcomes. Based on these findings, several laboratory tests to detect complement activation have been developed to predict the risk of antibody-mediated graft rejection in transplant recipients with DSA such as CDC crossmatch test, LMX-C4d assay and C1q assay. ${ }^{54,64,65,6867}$ Among these tests, assay of the classical complement pathway component, C1q, seems to be more sensitive and specific and correlated with post-transplant outcomes. ${ }^{34,67,68}$ In kidney transplantation, complement-binding DSA correlated with significantly higher rejection rate and worse survival ${ }^{74}$, while in hematopoietic stem cell transplantation, Ciurea et al. recently found that DSA that binds complement, detected by the C1q assay, associate with high MFI levels and very high likelihood of graft rejection in HHST recipients. ${ }^{34}$ In this study, virtually all patients who had C1q-fixing DSA at transplant rejected the graft, while patients who became $\mathrm{C} 1 \mathrm{q}$ negative through desensitization therapy engrafted the donor cells. ${ }^{34}$ To date, this remains the only study evaluating the role of complement-binding DSA in AHCT; however, taken together with data from solid organ transplantation, these data suggest an important role for complement-binding DSA in allograft rejection and the need to effectively desensitize patients with DSA prior to transplantation, as detailed later in this article.

Factors that influence the complement activation ability of DSA have not well understood. Previous studies by Chen showed that there is no predictability by IgG mean fluorescence intensity (MFI) as to which of the antibodies will bind C1q because fixation was independent of antibody intensity. ${ }^{65}$ However, most patients who had positive $\mathrm{C} 1 \mathrm{q}$ in the MDACC study had higher median MFI of DSAs levels (all more than 5,000 MFI) compared with those who had negative $\mathrm{C} 1 \mathrm{q} .{ }^{34}$ These results suggest that the possibility of complement fixation might depend on both ability and intensity of DSAs. Future prospective studies are needed to confirm the utility of testing not only for DSA but also for complement-binding ability of DSA in hematopoietic stem cell transplantation. Until then, based on limited experience but high likelihood of rejection, it is prudent to recommend testing for $\mathrm{C} 1 \mathrm{q}$ in addition to HLA antibodies testing, as patients with complement binding DSA have a much higher rejection rate than those without. Because $\mathrm{C} 1 \mathrm{q}$ testing this is not done yet in many centers and because of the high association with high DSA levels (>5,000 MFI), it should be presumed that high DSA levels are most likely complement-binding and treatment should be applied to all these patients prior to transplantation.

In conclusion, the exact mechanism by which DSA cause graft rejection in hematopoietic stem cell transplantation remains unclear. However, complement-mediated cytotoxicity appears to be involved and testing for complement-binding DSA (C1q) appears to be 
indicated in this setting. Persistent $\mathrm{C} 1 \mathrm{q}$ at transplant is very likely to be associated with graft rejection.

\section{Is there a DSA cutoff more detrimental to engraftment?}

A positive test for DSA is considered when MFI are above 1,000; however, the cut-off of MFI values used varies among transplant centers and laboratories. As previously discussed, this is a very sensitive test and the significance of low antibody levels remains unclear. Although rejection can occur at any DSA level for MFI $>1,000$, the likelihood of developing PGF increases as the MFI levels increase. As documented in several studies now, the incidence of PGF appears to increase with MFI levels above 5,000. ${ }^{34,37}$ The risk of rejection rate for patients with DSA $<5,000$ MFI was found to be $9 \%$ vs. $54 \%$ for patients with DSA $>5,000$ MFI. ${ }^{34}$ As mentioned above, higher MFI levels $(>5,000)$ correlate also with the complement-binding ability, which could contribute to a higher likelihood of rejection in these patients. ${ }^{34}$ It remains unclear whether some antibodies are more likely to bind complement or higher levels are more likely to activate complement cascade and destroy targeted cells.

\section{Prozone effect}

The MFI values derived from the multiplex-bead assays can be affected by multiple factors such as antigen density or denatured antigens on the beads, variations from lot-to-lot, run-torun, kit-to-kit from different manufactures. Another factor is the so called "prozone" phenomenon or the "hook" effect, in which high-titer antibodies as in highly sensitized patients could result in falsely negative or low results tested with sera "at neat", but would react strongly positive after dilution. In the last few years, protocols for serum treatment using dithiothreitol (DTT), ethylenediaminetetraacetic acid (EDTA), serum dilution or other methods aiming at resolving the prozone effect and unmask seemingly weak or false negative antibodies have been evaluated and adopted by many laboratories. ${ }^{75-78}$

In conclusion, evidence suggests that MFI levels $>5,000$ pose a much higher risk to engraftment although rejection can occur with DSA at any MFI levels. The high correlation with complement-binding DSA for levels >5,000 MFI suggest that patients with such levels should be tested also for C1q, as discussed above. However, caution should be taken when interpret MFI results and correlation with clinical outcome due to the semi-quantitative nature of the assays and potential variations from different factors as mentioned above. Center-specific or local validation and standardization of the antibody DSA detection assays including the MFI cut-off would be recommended at the present time.

\section{How do we treat patients with DSA before transplant?}

Transplantation using hematopoietic stem cells from a donor without corresponding HLA antigens is an ideal option for patients with the presence of circulating DSA since it has been shown in several studies that anti-HLA antibodies directed against other HLA antigens than the donor's HLA antigens do not increase the risk of PGF. ${ }^{33,40}$ However, this might not always be possible due to the limitation in donor availability and an urgent need to proceed to transplant. To reduce the risk of PGF, several desensitization methods have been used to 
decrease total antibody load to levels that would permit successful donor stem cell engraftment.

These strategies to desensititize patients with DSA are classified into the following 4 strategies: 1) antibody removal by using plasmapheresis or immunoabsorption; 2) inhibition of antibody production by using monoclonal antibodies to CD20+ B lymphocytes (rituximab), and proteasome inhibitor against alloantibody producing plasma cells (bortezomib); 3) antibody neutralization using intravenous immunoglobulin (IVIg), or with donor HLA antigens (platelet transfusions or white blood cell infusion in the form of an irradiated "buffy coat"); and 4) inhibition of complement cascade (Table 2). These desensitization methods are based on experiences in solid organ transplantation. ${ }^{79-83}$ Some of these interventions have also been used in HHCT and mismatched donor hematopoietic stem cell transplantation. However, most published data regarding transplant outcomes in AHCT patients receiving these desensitization methods are case reports or small studies with limited number of patients and variety of graft outcome (Table 3). ${ }^{34,}$, 37, 69, 84-87

Plasmapheresis is the most common method of desensitization used in both solid organ and AHCT patients. The use of plasmapheresis for desensitization in HHCT patients was first described by Barge et al. Though, using plasmapheresis alone in this study did not effectively prevent GF as the patient subsequently experienced GF and death. ${ }^{69}$ Therefore, the more recent protocols were the combination of plasmapheresis and other methods, which aim to inhibit antibody production and antibody neutralization. In the initial study by investigators from MDACC, the combination of plasmapheresis, IVIg and rituximab was used to treat 4 HHCT patients with DSA, 1 patient developed GF with persistent high DSA levels, while 3 engrafted, 2 of them in the absence of DSA. ${ }^{13}$ Some of the most impressive reductions of DSAs were achieved by using 40 units of platelet transfusion from healthy donors selected to have the HLA antigens corresponding to the DSAs. ${ }^{37,} 88$ Yoshihara et al. have tried 3 desensitization approaches for 5 patients who were to receive either bone marrow and peripheral blood stem cell grafts from haploidentical donors. Treatment regimen in this study was a combination of plasmapheresis, rituximab, antibody adsorption with platelets and administration of the proteasome inhibitor, bortezomib. One of the 2 patients treated with plasmapheresis and rituximab received plasmapheresis on day - 11 and the other received plasmapheresis on days $-17,-15$ and -13 . Both were given a single dose of rituximab at $375 \mathrm{mg} / \mathrm{m}^{2}$. DSA reduction was achieved in only 1 of 2 patients. However, both engrafted. ${ }^{37}$ In a case report by Yamashita et al., 1 patient who developed DSA after the first AHCT from cord blood stem cells was treated with a single dose of rituximab $375 \mathrm{mg} / \mathrm{m}^{2}$ on day -10 , IVIg $5 \mathrm{~g} /$ day for 4 days (day -8 to -5 ), and 20 units of platelets from healthy donor who had HLA corresponding to DSA 6 hours before undergoing second transplant from haploidentical donor. The serum MFI level was reduced significantly at the end of the platelet transfusion and donor neutrophil engraftment was successfully achieved. ${ }^{88}$ However, using platelet transfusions can only absorb DSA specific to class I HLA antigens as platelets have only class I HLA antigens on their surface. In the updated study, the MDACC group infused an irradiated "buffy coat" prepared from 1 unit of blood which was infused to 5 HHCT patients with DSA on transplant Day-1, in addition to 3 doses of alternating plasmapheresis every other day followed by 1 dose of IVIg and rituximab. The "buffy coat" containing all donor HLA antigens can potentially bind DSA specific to both class I and II 
donor HLA antigens. The buffy coat infusion resulted in C1q negativity in 2 previously C1q positive patients and all of them engrafted with the donor cells successfully, even though the reduction of DSA level was not immediate. Delay in clearance of DSA in most patients over the next few weeks after treatment has been reported both by the MDACC and Hopkins groups. ${ }^{34}$ The MDACC desensitization protocol is shown in Figure 2. Recently, we examined the effect of this treatment in a follow-up analysis of 48 patients with DSA (42 patients transplanted at MDACC and 6 at City of Hope Medical Center). Out of 48 patients, 22 patients did not receive any treatment prior to transplant, while 26 were treated, 16 with $\mathrm{PE} / \mathrm{R} / \mathrm{IVIg}+\mathrm{BC}$ and 10 received only PE/R/IVIg. The median MFI at diagnosis/before treatment and after treatment before transplant for patients who did not have treatment was 2,910 MFI and 2,906 MFI, respectively, while for patients who received treatment was 4,887 MFI and 2,906, respectively. Only 6 patients were tested for C1q in the untreated group, 2/6 $(33.3 \%)$ were $\mathrm{C} 1 \mathrm{q}+$ and both failed to engraft the donor cells for overall engraftment of $81 \%$, while of 26 patients with DSA who received treatment, 21 patients were tested for C1q and $13 / 21(62 \%)$ were $\mathrm{C} 1 \mathrm{q}+$ for an engraftment rate in the treatment group was $92.3 \%$. One patient failed to engraft in the R/PE/IVIg group (engraftment 90\%) and one failed to engraft in the R/PE/IVIg + BC group (engraftment 94\%). (unpublished data).

The Johns Hopkins group developed an alternative approach by extrapolating experience for desensitization in solid organ transplantation, using a combination of repeated plasmapheresis IVIg and immunosuppressive medications to suppress immune response caused by DSA. This protocol used in renal transplant recipients ${ }^{89}$ and has also been studied in 15 mismatched AHCT patients including 13 haploidentical transplant patients. ${ }^{87}$ The desensitization regimen consisted of alternate-day, single volume plasmapheresis followed by IVIg ( $100 \mathrm{mg} / \mathrm{kg})$, tacrolimus ( $1 \mathrm{mg}$, i.v. per day) and mycophenolate mofetil ( $1 \mathrm{~g}$ two times daily) starting 1-2 weeks before the beginning of transplant conditioning, depending on each patient's starting DSA levels. DSA levels were monitored throughout desensitization and on Day - 1 to determine if there was any DSA rebound that would require additional treatment. For patients experiencing an increase or rebound of DSA on Day $-1,1$ to 2 additional plasmapheresis and IVIg treatments were scheduled on Day +1 and Day +2 depending on the extent of the DSA increase. DSA in 11 patients was reduced to levels considered negative post-transplant, whereas DSA in 3 patients remained at low levels. All 14 patients achieved donor engraftment by Day $+60 .{ }^{87}$ However, it is important to mention that patients with very strong flow cytometric crossmatch do not undergo this procedure (Douglas Gladstone/Maria Bettinotti, personal communication, Sao Paolo, Brazil, 2017) and alternative donors are pursued. Even though this protocol could reduce the risk of GF, additional immunologic suppression after stem cell infusion could increase the risk of disease relapse since the treatment could potentially affect $\mathrm{T}$ cells in the infused stem cell product. In this study, 7 out of 14 patients suffered disease relapses post-transplant. ${ }^{87}$ Albeit, the majority of these studies have been anecdotal, included only a few patients, but taken together have indicated that reduction of DSA to low levels can permit successful engraftment.

In conclusion, patients with DSA should undergo desensitization prior to transplantation if a suitable donor without DSA against is not available for transplantation. Several 
desensitization strategies have been developed. Efficacy of these strategies will be tested in the future.

\section{How do we monitor treatment and DSA levels after treatment and transplant?}

DSA and C1q levels should be monitored before and after treatment, as well as after transplant. We recommend a repeat serum sample for DSA (and C1q if DSA present) at least within 1 month prior to admission. All patients with levels above 1,000-2,000 should receive treatment as discussed above. Repeated DSA levels should be considered at least after treatment/before infusion of stem cells and after transplant. We recommend weekly DSA levels monitoring thereafter until clearance, as DSA levels will not clear immediately after treatment and/or stem cell infusion. ${ }^{34,46}$ Patients with $\mathrm{C} 1 \mathrm{q}+$ should continue to have C1q testing with repeat DSA serum samples until negative.

In conclusion, enough evidence has been generated for uniform testing and treatment for patients with DSA prior to haploidentical stem cell transplantation. Although further studies on larger number of patients are needed, it is clear that there is a strong detrimental effect on engraftment and survival for patients with DSA. We recommend that: 1. DSA testing (by Luminex platform and/or cell-based assays) be performed in all candidate patients for haploidentical (or HLA mismatched) donor transplants; 2. If DSA >1,000 MFI, C1q testing and/or cell-based assays must be done to further assess the risk to the allograft; 3 . DSA testing should be incorporated in donor selection prior to transplantation; if DSA >1,000 MFI in the absence of an alternative suitable donor, it is recommended that patients undergo desensitization therapy, especially with high DSA levels (>5,000 MFI) and/or C1q positive, which pose a very high risk to the allograft; 4 . The choice of desensitization protocol may be based on prior local experience.

\section{References}

1. Airoldi I, Bertaina A, Prigione I, Zorzoli A, Pagliara D, Cocco C et al. gammadelta T-cell reconstitution after HLA-haploidentical hematopoietic transplantation depleted of TCR-alphabeta+/ CD19+ lymphocytes. Blood 2015; 125(15): 2349-2358. 10.1182/blood-2014-09-599423 [PubMed: 25612623]

2. Bertaina A, Merli P, Rutella S, Pagliara D, Bernardo ME, Masetti R et al. HLA-haploidentical stem cell transplantation after removal of alphabeta $\mathrm{T}$ and $\mathrm{B}$ cells in children with nonmalignant disorders. Blood 2014; 124(5): 822-826. 10.1182/blood-2014-03-563817 [PubMed: 24869942]

3. Ciurea SO, Zhang M-J, Bacigalupo A, Bashey A, Appelbaum FR, Antin JH et al. Survival after TCell Replete Haplo-Identical Related Donor Transplant Using Post-Transplant Cyclophosphamide Compared with Matched Unrelated Donor Transplant for Acute Myeloid Leukemia. Blood 2014; 124(21): 679-679. [PubMed: 24876560]

4. Edinger M, Hoffmann P, Ermann J, Drago K, Fathman CG, Strober S et al. CD4+CD25+ regulatory $\mathrm{T}$ cells preserve graft-versus-tumor activity while inhibiting graft-versus-host disease after bone marrow transplantation. Nature medicine 2003; 9(9): 1144-1150. 10.1038/nm915

5. Luznik L, O’Donnell PV, Symons HJ, Chen AR, Leffell MS, Zahurak M et al. HLA-haploidentical bone marrow transplantation for hematologic malignancies using nonmyeloablative conditioning and high-dose, posttransplantation cyclophosphamide. Biology of blood and marrow transplantation : journal of the American Society for Blood and Marrow Transplantation 2008; 14(6): 641-650. 10.1016/j.bbmt.2008.03.005 [PubMed: 18489989] 
6. Bastien JP, Krosl G, Therien C, Rashkovan M, Scotto C, Cohen S et al. Photodepletion differentially affects CD4+ Tregs versus CD4+ effector T cells from patients with chronic graft-versus-host disease. Blood 2010; 116(23): 4859-4869. 10.1182/blood-2010-03-273193 [PubMed: 20798236]

7. Peccatori J, Forcina A, Clerici D, Crocchiolo R, Vago L, Stanghellini MT et al. Sirolimus-based graft-versus-host disease prophylaxis promotes the in vivo expansion of regulatory $\mathrm{T}$ cells and permits peripheral blood stem cell transplantation from haploidentical donors. Leukemia 2015; 29(2): 396-405. 10.1038/leu.2014.180 [PubMed: 24897508]

8. Lee CJ, Savani BN, Mohty M, Labopin M, Ruggeri A, Schmid C et al. Haploidentical hematopoietic cell transplantation for adult acute myeloid leukemia: A position statement from the Acute Leukemia Working Party of the European Society for Blood and Marrow Transplantation. Haematologica 2017 10.3324/haematol.2017.176107

9. Rondon G, Saliba RM, Khouri I, Giralt S, Chan K, Jabbour E et al. Long-term follow-up of patients who experienced graft failure postallogeneic progenitor cell transplantation. Results of a single institution analysis. Biology of blood and marrow transplantation : journal of the American Society for Blood and Marrow Transplantation 2008; 14(8): 859-866. 10.1016/j.bbmt.2008.05.005 [PubMed: 18640568]

10. O’Reilly RJ, Keever C, Kernan NA, Brochstein J, Collins N, Flomenberg N et al. HLA nonidentical $\mathrm{T}$ cell depleted marrow transplants: a comparison of results in patients treated for leukemia and severe combined immunodeficiency disease. Transplantation proceedings 1987; 19(6 Suppl 7): 55-60. e-pub ahead of print 1987/12/01;

11. Ash RC, Horowitz MM, Gale RP, van Bekkum DW, Casper JT, Gordon-Smith EC et al. Bone marrow transplantation from related donors other than HLA-identical siblings: effect of $\mathrm{T}$ cell depletion. Bone marrow transplantation 1991; 7(6): 443-452. e-pub ahead of print 1991/06/01; [PubMed: 1873591]

12. Ciurea SO, Mulanovich V, Jiang Y, Bassett R, Rondon G, McMannis J et al. Lymphocyte recovery predicts outcomes in cord blood and T cell-depleted haploidentical stem cell transplantation. Biology of blood and marrow transplantation : journal of the American Society for Blood and Marrow Transplantation 2011; 17(8): 1169-1175. 10.1016/j.bbmt.2010.11.020 [PubMed: 21126598]

13. Ciurea SO, de Lima M, Cano P, Korbling M, Giralt S, Shpall EJ et al. High risk of graft failure in patients with anti-HLA antibodies undergoing haploidentical stem-cell transplantation. Transplantation 2009; 88(8): 1019-1024. 10.1097/TP.0b013e3181b9d710 [PubMed: 19855248]

14. Aversa F, Terenzi A, Tabilio A, Falzetti F, Carotti A, Ballanti S et al. Full haplotype-mismatched hematopoietic stem-cell transplantation: a phase II study in patients with acute leukemia at high risk of relapse. Journal of clinical oncology : official journal of the American Society of Clinical Oncology 2005; 23(15): 3447-3454. 10.1200/jco.2005.09.117 [PubMed: 15753458]

15. Ciceri F, Labopin M, Aversa F, Rowe JM, Bunjes D, Lewalle P et al. A survey of fully haploidentical hematopoietic stem cell transplantation in adults with high-risk acute leukemia: a risk factor analysis of outcomes for patients in remission at transplantation. Blood 2008; 112(9): 3574-3581. 10.1182/blood-2008-02-140095 [PubMed: 18606875]

16. Ciurea SO, Saliba R, Rondon G, Pesoa S, Cano P, Fernandez-Vina M et al. Reduced-intensity conditioning using fludarabine, melphalan and thiotepa for adult patients undergoing haploidentical SCT. Bone marrow transplantation 2010; 45(3): 429-436. 10.1038/bmt.2009.189 [PubMed: 19668237]

17. Wang Y, Chang YJ, Xu LP, Liu KY, Liu DH, Zhang XH et al. Who is the best donor for a related HLA haplotype-mismatched transplant? Blood 2014; 124(6): 843-850. 10.1182/ blood-2014-03-563130 [PubMed: 24916508]

18. Raiola AM, Dominietto A, Ghiso A, Di Grazia C, Lamparelli T, Gualandi F et al. Unmanipulated haploidentical bone marrow transplantation and posttransplantation cyclophosphamide for hematologic malignancies after myeloablative conditioning. Biology of blood and marrow transplantation : journal of the American Society for Blood and Marrow Transplantation 2013; 19(1): 117-122. 10.1016/j.bbmt.2012.08.014 [PubMed: 22940057]

19. Rubio MT, Savani BN, Labopin M, Piemontese S, Polge E, Ciceri F et al. Impact of conditioning intensity in T-replete haplo-identical stem cell transplantation for acute leukemia: a report from the 
acute leukemia working party of the EBMT. Journal of hematology \& oncology 2016; 9: 25 10.1186/s13045-016-0248-3 [PubMed: 26980295]

20. Davies SM, Kollman C, Anasetti C, Antin JH, Gajewski J, Casper JT et al. Engraftment and survival after unrelated-donor bone marrow transplantation: a report from the national marrow donor program. Blood 2000; 96(13): 4096-4102. e-pub ahead of print 2000/12/09; [PubMed: 11110679]

21. Rubinstein P, Carrier C, Scaradavou A, Kurtzberg J, Adamson J, Migliaccio AR et al. Outcomes among 562 recipients of placental-blood transplants from unrelated donors. The New England journal of medicine 1998; 339(22): 1565-1577. 10.1056/nejm199811263392201 [PubMed: 9828244]

22. Murphy WJ, Kumar V, Bennett M. Acute rejection of murine bone marrow allografts by natural killer cells and T cells. Differences in kinetics and target antigens recognized. The Journal of experimental medicine 1987; 166(5): 1499-1509. e-pub ahead of print 1987/11/01; [PubMed: 3316472]

23. Bordignon C, Kernan NA, Keever CA, Benazzi E, Small TN, Brochstein J et al. The role of residual host immunity in graft failures following T-cell-depleted marrow transplants for leukemia. Annals of the New York Academy of Sciences 1987; 511: 442-446. e-pub ahead of print 1987/01/01; [PubMed: 3326473]

24. Anasetti C, Logan BR, Confer DL. Peripheral-blood versus bone marrow stem cells. The New England journal of medicine 2013; 368(3): 288 10.1056/NEJMc1214025 [PubMed: 23323911]

25. van Besien K, Shore T, Cushing M. Peripheral-blood versus bone marrow stem cells. The New England journal of medicine 2013; 368(3): 287-288. 10.1056/NEJMc1214025\#SA1

26. Anasetti C, Logan BR, Lee SJ, Waller EK, Weisdorf DJ, Wingard JR et al. Peripheral-blood stem cells versus bone marrow from unrelated donors. The New England journal of medicine 2012; 367(16): 1487-1496. 10.1056/NEJMoa1203517 [PubMed: 23075175]

27. Slot S, Smits K, van de Donk NW, Witte BI, Raymakers R, Janssen JJ et al. Effect of conditioning regimens on graft failure in myelofibrosis: a retrospective analysis. Bone marrow transplantation 2015; 50(11): 1424-1431. 10.1038/bmt.2015.172 [PubMed: 26237165]

28. Bacigalupo A, Dominietto A, Ghiso A, Di Grazia C, Lamparelli T, Gualandi F et al. Unmanipulated haploidentical bone marrow transplantation and post-transplant cyclophosphamide for hematologic malignanices following a myeloablative conditioning: an update. Bone marrow transplantation 2015; 50 Suppl 2: S37-39. 10.1038/bmt.2015.93 [PubMed: 26039205]

29. Solomon SR, Sizemore CA, Sanacore M, Zhang X, Brown S, Holland HK et al. Total Body Irradiation-Based Myeloablative Haploidentical Stem Cell Transplantation Is a Safe and Effective Alternative to Unrelated Donor Transplantation in Patients Without Matched Sibling Donors. Biology of blood and marrow transplantation : journal of the American Society for Blood and Marrow Transplantation 2015; 21(7): 1299-1307. 10.1016/j.bbmt.2015.03.003 [PubMed: 25797174]

30. Canaani J, Savani BN, Labopin M, Huang XJ, Ciceri F, Arcese W et al. Impact of ABO incompatibility on patients' outcome after haploidentical hematopoietic stem cell transplantation for acute myeloid leukemia - a report from the Acute Leukemia Working Party of the EBMT. Haematologica 2017; 102(6): 1066-1074. 10.3324/haematol.2016.160804 [PubMed: 28255020]

31. Warren RP, Storb R, Weiden PL, Su PJ, Thomas ED. Lymphocyte-mediated cytotoxicity and antibody-dependent cell-mediated cytotoxicity in patients with aplastic anemia: distinguishing transfusion-induced sensitization from possible immune-mediated aplastic anemia. Transplantation proceedings 1981; 13(1 Pt 1): 245-247. e-pub ahead of print 1981/03/01; [PubMed: 7022832]

32. Xu H, Chilton PM, Tanner MK, Huang Y, Schanie CL, Dy-Liacco M et al. Humoral immunity is the dominant barrier for allogeneic bone marrow engraftment in sensitized recipients. Blood 2006; 108(10): 3611-3619. 10.1182/blood-2006-04-017467 [PubMed: 16888094]

33. Ciurea SO, Thall PF, Wang X, Wang SA, Hu Y, Cano P et al. Donor-specific anti-HLA Abs and graft failure in matched unrelated donor hematopoietic stem cell transplantation. Blood 2011; 118(22): 5957-5964. 10.1182/blood-2011-06-362111 [PubMed: 21967975]

34. Ciurea SO, Thall PF, Milton DR, Barnes TH, Kongtim P, Carmazzi Y et al. Complement-Binding Donor-Specific Anti-HLA Antibodies and Risk of Primary Graft Failure in Hematopoietic Stem Cell Transplantation. Biology of blood and marrow transplantation : journal of the American 
Society for Blood and Marrow Transplantation 2015; 21(8): 1392-1398. 10.1016/

j.bbmt.2015.05.001 [PubMed: 25985919]

35. Butler CL, Valenzuela NM, Thomas KA, Reed EF. Not All Antibodies Are Created Equal: Factors That Influence Antibody Mediated Rejection. Journal of immunology research 2017; 2017: $10.1155 / 2017 / 7903471$

36. Taylor PA, Ehrhardt MJ, Roforth MM, Swedin JM, Panoskaltsis-Mortari A, Serody JS et al. Preformed antibody, not primed T cells, is the initial and major barrier to bone marrow engraftment in allosensitized recipients. Blood 2007; 109(3): 1307-1315. 10.1182/ blood-2006-05-022772 [PubMed: 17018854]

37. Yoshihara S, Maruya E, Taniguchi K, Kaida K, Kato R, Inoue T et al. Risk and prevention of graft failure in patients with preexisting donor-specific HLA antibodies undergoing unmanipulated haploidentical SCT. Bone marrow transplantation 2012; 47(4): 508-515. 10.1038/bmt.2011.131 [PubMed: 21691261]

38. Chang YJ, Zhao XY, Xu LP, Zhang XH, Wang Y, Han W et al. Donor-specific anti-human leukocyte antigen antibodies were associated with primary graft failure after unmanipulated haploidentical blood and marrow transplantation: a prospective study with randomly assigned training and validation sets. Journal of hematology \& oncology 2015; 8: 84 10.1186/ s13045-015-0182-9 [PubMed: 26156584]

39. Spellman S, Bray R, Rosen-Bronson S, Haagenson M, Klein J, Flesch S et al. The detection of donor-directed, HLA-specific alloantibodies in recipients of unrelated hematopoietic cell transplantation is predictive of graft failure. Blood 2010; 115(13): 2704-2708. 10.1182/ blood-2009-09-244525 [PubMed: 20089963]

40. Takanashi M, Atsuta Y, Fujiwara K, Kodo H, Kai S, Sato H et al. The impact of anti-HLA antibodies on unrelated cord blood transplantations. Blood 2010; 116(15): 2839-2846. 10.1182/ blood-2009-10-249219 [PubMed: 20628152]

41. Brunstein CG, Noreen H, DeFor TE, Maurer D, Miller JS, Wagner JE. Anti-HLA antibodies in double umbilical cord blood transplantation. Biology of blood and marrow transplantation : journal of the American Society for Blood and Marrow Transplantation 2011; 17(11): 1704-1708. 10.1016/j.bbmt.2011.04.013 [PubMed: 21601639]

42. Cutler C, Kim HT, Sun L, Sese D, Glotzbecker B, Armand P et al. Donor-specific anti-HLA antibodies predict outcome in double umbilical cord blood transplantation. Blood 2011; 118(25): 6691-6697. 10.1182/blood-2011-05-355263 [PubMed: 21940825]

43. Ruggeri A, Rocha V, Masson E, Labopin M, Cunha R, Absi L et al. Impact of donor-specific antiHLA antibodies on graft failure and survival after reduced intensity conditioning-unrelated cord blood transplantation: a Eurocord, Societe Francophone d'Histocompatibilite et d'Immunogenetique (SFHI) and Societe Francaise de Greffe de Moelle et de Therapie Cellulaire (SFGM-TC) analysis. Haematologica 2013; 98(7): 1154-1160. 10.3324/haematol.2012.077685 [PubMed: 23242594]

44. Takanashi M, Fujiwara K, Tanaka H, Satake M, Nakajima K. The impact of HLA antibodies on engraftment of unrelated cord blood transplants. Transfusion 2008; 48(4): 791-793. 10.1111/ j.1537-2995.2008.01678.x [PubMed: 18366463]

45. Picascia A, Grimaldi V, Napoli C. From HLA typing to anti-HLA antibody detection and beyond: The road ahead. Transplantation reviews (Orlando, Fla.) 2016; 30(4): 187-194. 10.1016/ j.trre.2016.07.007

46. Gladstone DE, Zachary AA, Fuchs EJ, Luznik L, Kasamon YL, King KE et al. Partially mismatched transplantation and human leukocyte antigen donor-specific antibodies. Biology of blood and marrow transplantation : journal of the American Society for Blood and Marrow Transplantation 2013; 19(4): 647-652. 10.1016/j.bbmt.2013.01.016 [PubMed: 23353119]

47. Morin-Papunen L, Tiilikainen A, Hartikainen-Sorri AL. Maternal HLA immunization during pregnancy: presence of anti HLA antibodies in half of multigravidous women. Medical biology 1984; 62(6): 323-325. e-pub ahead of print 1984/01/01; [PubMed: 6598218]

48. Vichinsky EP, Earles A, Johnson RA, Hoag MS, Williams A, Lubin B. Alloimmunization in sickle cell anemia and transfusion of racially unmatched blood. The New England journal of medicine 1990; 322(23): 1617-1621. 10.1056/nejm199006073222301 [PubMed: 2342522] 
49. Ferrandiz I, Congy-Jolivet N, Del Bello A, Debiol B, Trebern-Launay K, Esposito L et al. Impact of early blood transfusion after kidney transplantation on the incidence of donor-specific anti-HLA antibodies. American journal of transplantation : official journal of the American Society of Transplantation and the American Society of Transplant Surgeons 2016 10.1111/ajt.13795

50. Yabu JM, Anderson MW, Kim D, Bradbury BD, Lou CD, Petersen J et al. Sensitization from transfusion in patients awaiting primary kidney transplant. Nephrology, dialysis, transplantation : official publication of the European Dialysis and Transplant Association - European Renal Association 2013; 28(11): 2908-2918. 10.1093/ndt/gft362

51. Aalten J, Bemelman FJ, van den Berg-Loonen EM, Claas FH, Christiaans MH, de Fijter JW et al. Pre-kidney-transplant blood transfusions do not improve transplantation outcome: a Dutch national study. Nephrology, dialysis, transplantation : official publication of the European Dialysis and Transplant Association - European Renal Association 2009; 24(8): 2559-2566. 10.1093/ndt/ gfp233

52. Balasubramaniam GS, Morris M, Gupta A, Mesa IR, Thuraisingham R, Ashman N. Allosensitization rate of male patients awaiting first kidney grafts after leuko-depleted blood transfusion. Transplantation 2012; 93(4): 418-422. 10.1097/TP.0b013e3182419864 [PubMed: 22228416]

53. Rees L, Kim JJ. HLA sensitisation: can it be prevented? Pediatric nephrology (Berlin, Germany) 2015; 30(4): 577-587. 10.1007/s00467-014-2868-6

54. Patel R, Terasaki PI. Significance of the positive crossmatch test in kidney transplantation. The New England journal of medicine 1969; 280(14): 735-739. 10.1056/nejm196904032801401 [PubMed: 4886455]

55. Pena JR, Saidman SL. Anti-HLA antibody testing in hematology patients. American journal of hematology 2015; 90(4): 361-364. 10.1002/ajh.23935 [PubMed: 25580568]

56. Kissmeyer-Nielsen F, Olsen S, Petersen VP, Fjeldborg O. Hyperacute rejection of kidney allografts, associated with pre-existing humoral antibodies against donor cells. Lancet (London, England) 1966; 2(7465): 662-665. e-pub ahead of print 1966/09/24;

57. Tait BD, Susal C, Gebel HM, Nickerson PW, Zachary AA, Claas FH et al. Consensus guidelines on the testing and clinical management issues associated with HLA and non-HLA antibodies in transplantation. Transplantation 2013; 95(1): 19-47. 10.1097/TP.0b013e31827a19cc [PubMed: 23238534]

58. Couzi L, Araujo C, Guidicelli G, Bachelet T, Moreau K, Morel D et al. Interpretation of positive flow cytometric crossmatch in the era of the single-antigen bead assay. Transplantation 2011; 91(5): 527-535. 10.1097/TP.0b013e31820794bb [PubMed: 21192319]

59. Zachary AA, Ratner LE, Graziani JA, Lucas DP, Delaney NL, Leffell MS. Characterization of HLA class I specific antibodies by ELISA using solubilized antigen targets: II. Clinical relevance. Human immunology 2001; 62(3): 236-246. e-pub ahead of print 2001/03/16; [PubMed: 11250041]

60. Pei R, Lee J, Chen T, Rojo S, Terasaki PI. Flow cytometric detection of HLA antibodies using a spectrum of microbeads. Human immunology 1999; 60(12): 1293-1302. e-pub ahead of print 2000/01/08; [PubMed: 10626745]

61. Pei R, Lee JH, Shih NJ, Chen M, Terasaki PI. Single human leukocyte antigen flow cytometry beads for accurate identification of human leukocyte antigen antibody specificities. Transplantation 2003; 75(1): 43-49. 10.1097/01.tp.0000040431.80510.98 [PubMed: 12544869]

62. Taylor CJ, Kosmoliaptsis V, Summers DM, Bradley JA. Back to the future: application of contemporary technology to long-standing questions about the clinical relevance of human leukocyte antigen-specific alloantibodies in renal transplantation. Human immunology 2009; 70(8): 563-568. 10.1016/j.humimm.2009.05.001 [PubMed: 19445992]

63. Bartel G, Wahrmann M, Exner M, Regele H, Huttary N, Schillinger M et al. In vitro detection of C4d-fixing HLA alloantibodies: associations with capillary C4d deposition in kidney allografts. American journal of transplantation : official journal of the American Society of Transplantation and the American Society of Transplant Surgeons 2008; 8(1): 41-49. 10.1111/ j.1600-6143.2007.01998.x

64. Smith JD, Hamour IM, Banner NR, Rose ML. C4d fixing, luminex binding antibodies - a new tool for prediction of graft failure after heart transplantation. American journal of transplantation : 
official journal of the American Society of Transplantation and the American Society of Transplant Surgeons 2007; 7(12): 2809-2815. 10.1111/j.1600-6143.2007.01991.x

65. Chen G, Sequeira F, Tyan DB. Novel C1q assay reveals a clinically relevant subset of human leukocyte antigen antibodies independent of immunoglobulin $\mathrm{G}$ strength on single antigen beads. Human immunology 2011; 72(10): 849-858. 10.1016/j.humimm.2011.07.001 [PubMed: 21791230]

66. Chin C, Chen G, Sequeria F, Berry G, Siehr S, Bernstein D et al. Clinical usefulness of a novel C1q assay to detect immunoglobulin $\mathrm{G}$ antibodies capable of fixing complement in sensitized pediatric heart transplant patients. The Journal of heart and lung transplantation : the official publication of the International Society for Heart Transplantation 2011; 30(2): 158-163. 10.1016/ j.healun.2010.08.020

67. Yabu JM, Higgins JP, Chen G, Sequeira F, Busque S, Tyan DB. C1q-fixing human leukocyte antigen antibodies are specific for predicting transplant glomerulopathy and late graft failure after kidney transplantation. Transplantation 2011; 91(3): 342-347. 10.1097/TP.0b013e318203fd26 [PubMed: 21116220]

68. Sutherland SM, Chen G, Sequeira FA, Lou CD, Alexander SR, Tyan DB. Complement-fixing donor-specific antibodies identified by a novel C1q assay are associated with allograft loss. Pediatric transplantation 2012; 16(1): 12-17. 10.1111/j.1399-3046.2011.01599.x [PubMed: 22093755]

69. Barge AJ, Johnson G, Witherspoon R, Torok-Storb B. Antibody-mediated marrow failure after allogeneic bone marrow transplantation. Blood 1989; 74(5): 1477-1480. e-pub ahead of print 1989/10/01; [PubMed: 2790180]

70. Damman J, Seelen MA, Moers C, Daha MR, Rahmel A, Leuvenink HG et al. Systemic complement activation in deceased donors is associated with acute rejection after renal transplantation in the recipient. Transplantation 2011; 92(2): 163-169. 10.1097/ TP.0b013e318222c9a0 [PubMed: 21677599]

71. Muller TF, Kraus M, Neumann C, Lange H. Detection of renal allograft rejection by complement components C5A and TCC in plasma and urine. The Journal of laboratory and clinical medicine 1997; 129(1): 62-71. e-pub ahead of print 1997/01/01; [PubMed: 9011592]

72. Welch TR, Beischel LS, Witte DP. Differential expression of complement C3 and C4 in the human kidney. The Journal of clinical investigation 1993; 92(3): 1451-1458. 10.1172/jci116722 [PubMed: 8376597]

73. Keslar K, Rodriguez ER, Tan CD, Starling RC, Heeger PS. Complement gene expression in human cardiac allograft biopsies as a correlate of histologic grade of injury. Transplantation 2008; 86(9): 1319-1321. 10.1097/TP.0b013e3181889831 [PubMed: 19005416]

74. Loupy A, Lefaucheur C, Vernerey D, Prugger C, Duong van Huyen JP, Mooney N et al. Complement-binding anti-HLA antibodies and kidney-allograft survival. The New England journal of medicine 2013; 369(13): 1215-1226. 10.1056/NEJMoa1302506 [PubMed: 24066742]

75. Wang J, Meade JR, Brown NK, Weidner JG, Marino SR. EDTA is superior to DTT treatment for overcoming the prozone effect in HLA antibody testing. Hla 2017; 89(2): 82-89. 10.1111/ tan.12950 [PubMed: 28102038]

76. Anani WQ, Zeevi A, Lunz JG. EDTA Treatment of Serum Unmasks Complement-Mediated Prozone Inhibition in Human Leukocyte Antigen Antibody Testing. American journal of clinical pathology 2016; 146(3): 346-352. 10.1093/ajcp/aqw116 [PubMed: 27543980]

77. Weinstock C, Schnaidt M. The complement-mediated prozone effect in the Luminex single-antigen bead assay and its impact on HLA antibody determination in patient sera. International journal of immunogenetics 2013; 40(3): 171-177. 10.1111/j.1744-313X.2012.01147.x [PubMed: 22913810]

78. Schnaidt M, Weinstock C, Jurisic M, Schmid-Horch B, Ender A, Wernet D. HLA antibody specification using single-antigen beads--a technical solution for the prozone effect. Transplantation 2011; 92(5): 510-515. 10.1097/TP.0b013e31822872dd [PubMed: 21869744]

79. Ratkovec RM, Hammond EH, O'Connell JB, Bristow MR, DeWitt CW, Richenbacher WE et al. Outcome of cardiac transplant recipients with a positive donor-specific crossmatch--preliminary results with plasmapheresis. Transplantation 1992; 54(4): 651-655. e-pub ahead of print 1992/10/01; [PubMed: 1412756] 
80. Pisani BA, Mullen GM, Malinowska K, Lawless CE, Mendez J, Silver MA et al. Plasmapheresis with intravenous immunoglobulin $\mathrm{G}$ is effective in patients with elevated panel reactive antibody prior to cardiac transplantation. The Journal of heart and lung transplantation : the official publication of the International Society for Heart Transplantation 1999; 18(7): 701-706. e-pub ahead of print 1999/08/19;

81. Grauhan O, Knosalla C, Ewert R, Hummel M, Loebe M, Weng YG et al. Plasmapheresis and cyclophosphamide in the treatment of humoral rejection after heart transplantation. The Journal of heart and lung transplantation : the official publication of the International Society for Heart Transplantation 2001; 20(3): 316-321. e-pub ahead of print 2001/03/21;

82. Baran DA, Lubitz S, Alvi S, Fallon JT, Kaplan S, Galin I et al. Refractory humoral cardiac allograft rejection successfully treated with a single dose of rituximab. Transplantation proceedings 2004; 36(10): 3164-3166. 10.1016/j.transproceed.2004.10.087 [PubMed: 15686719]

83. Everly JJ, Walsh RC, Alloway RR, Woodle ES. Proteasome inhibition for antibody-mediated rejection. Current opinion in organ transplantation 2009; 14(6): 662-666. 10.1097/ MOT.0b013e328330f304 [PubMed: 19667989]

84. Maruta A, Fukawa H, Kanamori H, Harano H, Noguchi T, Kodama F et al. Donor-HLAincompatible marrow transplantation with an anti-donor cytotoxic antibody in the serum of the patient. Bone marrow transplantation 1991; 7(5): 397-400. e-pub ahead of print 1991/05/01; [PubMed: 2070151]

85. Braun N, Faul C, Wernet D, Schnaidt M, Stuhler G, Kanz L et al. Successful transplantation of highly selected CD34+ peripheral blood stem cells in a HLA-sensitized patient treated with immunoadsorption onto protein A. Transplantation 2000; 69(8): 1742-1744. e-pub ahead of print 2000/06/03; [PubMed: 10836395]

86. Pollack MS, Ririe D. Clinical significance of recipient antibodies to stem cell donor mismatched class I HLA antigens. Human immunology 2004; 65(3): 245-247. 10.1016/j.humimm.2003.12.010 [PubMed: 15041163]

87. Leffell MS, Jones RJ, Gladstone DE. Donor HLA-specific Abs: to BMT or not to BMT? Bone marrow transplantation 2015; 50(6): 751-758. 10.1038/bmt.2014.331 [PubMed: 25706884]

88. Yamashita T, Ikegame K, Kojima H, Tanaka H, Kaida K, Inoue T et al. Effective desensitization of donor-specific HLA antibodies using platelet transfusion bearing targeted HLA in a case of HLAmismatched allogeneic stem cell transplantation. Bone marrow transplantation 2017; 52(5): $794-$ 796. 10.1038/bmt.2017.10 [PubMed: 28165448]

89. Montgomery RA, Lonze BE, King KE, Kraus ES, Kucirka LM, Locke JE et al. Desensitization in HLA-incompatible kidney recipients and survival. The New England journal of medicine 2011; 365(4): 318-326. 10.1056/NEJMoa1012376 [PubMed: 21793744]

90. Kongtim P, Cao K, Ciurea SO. Donor Specific Anti-HLA Antibody and Risk of Graft Failure in Haploidentical Stem Cell Transplantation. Advances in hematology 2016; 2016: 4025073 10.1155/2016/4025073 [PubMed: 26904122]

91. Ottinger HD, Rebmann V, Pfeiffer KA, Beelen DW, Kremens B, Runde V et al. Positive serum crossmatch as predictor for graft failure in HLA-mismatched allogeneic blood stem cell transplantation. Transplantation 2002; 73(8): 1280-1285. e-pub ahead of print 2002/05/01; [PubMed: 11981422]

92. Narimatsu H, Wake A, Miura Y, Tanaka H, Matsumura T, Takagi S et al. Successful engraftment in crossmatch-positive HLA-mismatched peripheral blood stem cell transplantation after depletion of antidonor cytotoxic HLA antibodies with rituximab and donor platelet infusion. Bone marrow transplantation 2005; 36(6): 555-556. 10.1038/sj.bmt.1705070 [PubMed: 16007108] 


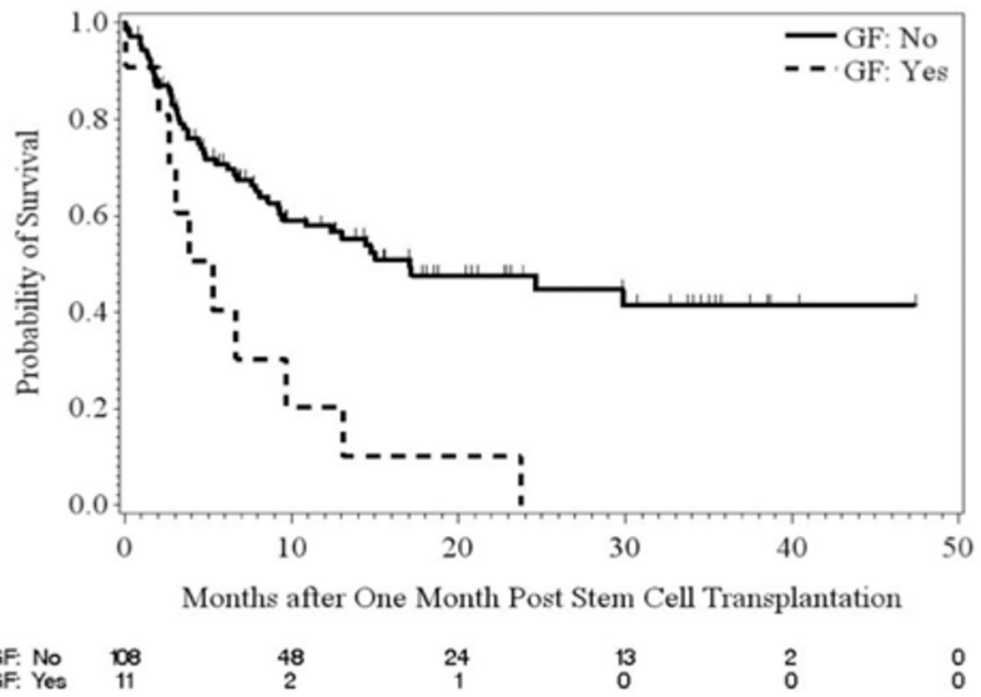

Figure 1.

Survival of haploidentical transplants for patients who experience primary graft failure as compared with those who engrafted the donor cells (Reproduced with permission from Ciurea SO, et al. Biol Blood Marrow Transplant. 2015) ${ }^{34}$ 


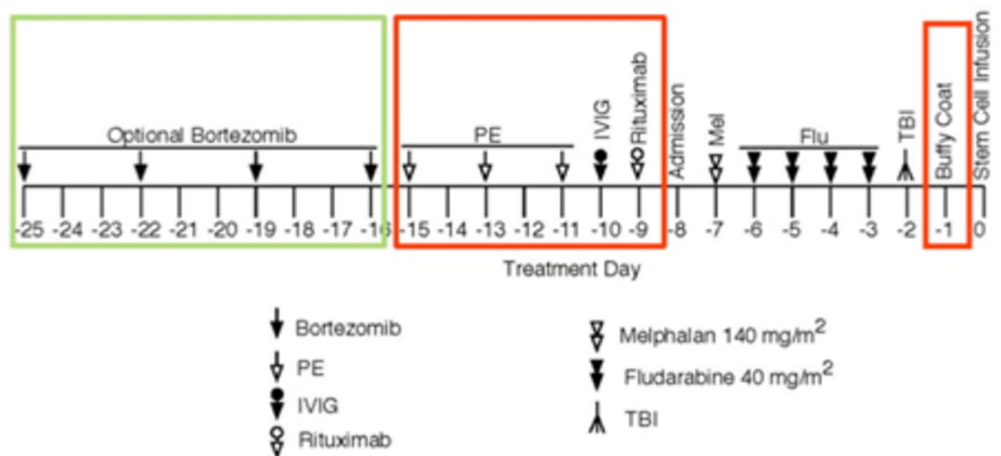

Figure 2.

Desensitization approach for patients with DSAs undergoing haploidentical stem cell transplantation at MD Anderson Cancer Center (Reproduced with permission from Kongtim P, et al. Advances in hematology.2016 ${ }^{90}$ ) 
Table 1.

Differences between various tests performed to determine the presence of DSA.

\begin{tabular}{|c|c|c|}
\hline Method & Direct crossmatch assays (CDC, FXM) & Virtual crossmatch assays (SPA) \\
\hline Patient's serum needed & Yes & Yes \\
\hline $\begin{array}{l}\text { Donor's viable lymphocytes } \\
\text { needed }\end{array}$ & Yes & No \\
\hline $\begin{array}{l}\text { Interference by biologic } \\
\text { antibodies (i.e., anti-CD20, } \\
\text { anti-CD52, etc.) }\end{array}$ & $\begin{array}{l}\text { Yes } \\
\text { Increase false-positive results }\end{array}$ & No \\
\hline Interference with IVIG & $\begin{array}{l}\text { Yes } \\
\text { Increase false-positive results } \\
\text { (avoid IVIG infusion } 1-2 \text { weeks prior to } \\
\text { testing) }\end{array}$ & $\begin{array}{l}\text { Yes } \\
\text { Increase false-positive results } \\
\text { (avoid IVIG infusion } 1-2 \text { weeks prior to testing) }\end{array}$ \\
\hline Ease of testing & $\begin{array}{l}\text { Cumbersome with requirement of donor's } \\
\text { lymphocytes }\end{array}$ & Simpler and faster \\
\hline Retesting & New collection of viable T-cells from the donor & $\begin{array}{l}\text { Stored DNA from previous samples from the donor (in } \\
\text { the event HLA-specific antibodies were present } \\
\text { previously) }\end{array}$ \\
\hline Specificity & Low (interferences by other methods) & $\begin{array}{l}\text { High (single antigen SPA) (method used in our centers) } \\
\text { Intermediate (phenotype SPA) }\end{array}$ \\
\hline Sensitivity & $\begin{array}{l}\text { Low (CDC) } \\
\text { High (FXM) }\end{array}$ & $\begin{array}{l}\text { High (single antigen SPA) (method used in most centers) } \\
\text { Intermediate (phenotype SPA) }\end{array}$ \\
\hline
\end{tabular}

SPA - solid phase assays, IVIG - intravenous immunoglobulin, CDC - complement dependent cytotoxicity, FXM - flow cytometric cross-match. 
Table 2.

Various desensitization strategies employed to date.

\begin{tabular}{|l|l|}
\hline \multicolumn{1}{|c|}{ Strategy } & \multicolumn{1}{c|}{ Method } \\
\hline Antibody removal & $\begin{array}{l}\text { Plasmapheresis } \\
\text { Immunoadsorption }\end{array}$ \\
\hline Antibody neutralization/enhance the clearance of anti-HLA antibodies & $\begin{array}{l}\text { Intravenous immunoglobulin } \\
\text { Donor platelets or "buffy coat" (white blood cells) infusion }\end{array}$ \\
\hline Inhibition of antibody production & $\begin{array}{l}\text { Anti-CD20+ B cells monoclonal antibody: rituximab } \\
\text { Proteazome inhibition: bortezomib } \\
\text { Splenectomy }\end{array}$ \\
\hline Complement cascade blockage & $\begin{array}{l}\text { Anti-C5a: Eculizumab } \\
\text { Intravenous immunoglobulin }\end{array}$ \\
\hline
\end{tabular}

Not used in hematopoietic stem cell transplantation to date 
Table 3.

DSA desensitization in haploidentical and mismatched related AHCT (Adapted from Kongtim P, et al. Advances in hematology. $2016^{90}$ )

\begin{tabular}{|c|c|c|c|c|c|}
\hline Reference & Donor type (N) & $\begin{array}{l}\text { Anti-HLA } \\
\text { abs test }\end{array}$ & Desensitization method & MFI post-treatment & Graft outcome \\
\hline Barge $1989^{69}$ & Haplo $(\mathrm{N}=1)$ & $\mathrm{CDC}$ & Plasmapheresis & NA & Graft failure \\
\hline $\begin{array}{l}\text { Maruta } \\
1991^{84}\end{array}$ & $\begin{array}{l}\text { Mismatched } \\
\text { related }(\mathrm{N}=1)\end{array}$ & AHG-CDC & $\begin{array}{l}\text { CyA, Methylprednisolone, } \\
\text { Plasmapheresis, DLI }\end{array}$ & Negative XM & Engrafted \\
\hline Braun $2000^{85}$ & Haplo $(\mathrm{N}=1)$ & FCXM & $\begin{array}{l}\text { Staphylococcal protein A } \\
\text { immunoadsorption }\end{array}$ & Negative XM & Engrafted \\
\hline $\begin{array}{l}\text { Ottinger } \\
2002^{91}\end{array}$ & $\begin{array}{l}\text { Mismatched } \\
\text { related }(\mathrm{N}=2)\end{array}$ & DTT-CDC & $\begin{array}{l}\text { Plasmapheresis, mismatched } \\
\text { platelet transfusion }\end{array}$ & $\begin{array}{l}1 \text { patient with negative XM, } 1 \\
\text { patient with positive XM }\end{array}$ & $\begin{array}{l}\text { Patient with } \\
\text { negative XM post- } \\
\text { treatment engrafted, } \\
\text { while patients with } \\
\text { positive XM had GF }\end{array}$ \\
\hline $\begin{array}{l}\text { Pollack } \\
2004^{86}\end{array}$ & $\begin{array}{l}\text { Mismatched } \\
\text { HLA-A68 } \\
\text { related }(\mathrm{N}=1)\end{array}$ & FCXM & $\begin{array}{l}\text { Platelet transfusion, } \\
\text { plasmapheresis, IVIg }\end{array}$ & Negative XM & Engrafted \\
\hline $\begin{array}{l}\text { Narimatsu } \\
2005^{92}\end{array}$ & $\begin{array}{l}\text { Mismatched } \\
\text { related }(\mathrm{N}=1)\end{array}$ & AHG-LCT & $\begin{array}{l}\text { Rituximab, platelet } \\
\text { transfusion }\end{array}$ & Negative AHG-LCT & Engrafted \\
\hline $\begin{array}{l}\text { Ciurea } \\
2009^{13}\end{array}$ & Haplo (N=4) & $\begin{array}{l}\text { Luminex } \\
\text { MFI }>500\end{array}$ & Plasmapheresis + rituximab & $\begin{array}{l}1 \text { negative, } 1 \text { low titer, } 2 \text { high } \\
\text { titer }\end{array}$ & $\begin{array}{l}\text { Patients with DSAs } \\
\text { negative and low } \\
\text { titer post treatment } \\
\text { engrafted, } 2 \text { patients } \\
\text { with high titer had } \\
\text { GF }\end{array}$ \\
\hline $\begin{array}{l}\text { Yoshihara } \\
2012^{37}\end{array}$ & Haplo (N=5) & $\begin{array}{l}\text { Luminex } \\
\text { MFI }>500\end{array}$ & $\begin{array}{l}\text { Plasmapheresis + rituximab } \\
(\mathrm{N}=2) \text {, platelet transfusions } \\
(\mathrm{N}=2) \text {, bortezomib }+ \\
\text { dexamethasone }(\mathrm{N}=1)\end{array}$ & $\begin{array}{l}1 \text { patient had temporary DSA } \\
\text { reduction and } 1 \text { patient had } \\
\text { significant reduction post } \\
\text { plasmapheresis, } 2 \text { patients had } \\
\text { a significant reduction post } \\
\text { platelet transfusion, } 1 \text { patient } \\
\text { had moderate DSA reduction } \\
\text { after bortezomib and dexa. }\end{array}$ & $\begin{array}{l}\text { All } 5 \text { patients } \\
\text { engrafted }\end{array}$ \\
\hline $\begin{array}{l}\text { Ciurea } \\
2015^{34}\end{array}$ & Haplo $(\mathrm{N}=12)$ & $\begin{array}{l}\text { Luminex } \\
\text { MFI }>500\end{array}$ & $\begin{array}{l}\text { Plasmapheresis + } \\
\text { rituximab, + IVIg }(\mathrm{N}=5), \mathrm{PE} \\
\text { + rituximab + IVIg + donor } \\
\text { "buffy coat" infusion }(\mathrm{N}=7)\end{array}$ & $\begin{array}{l}\text { No significant change of MFI } \\
\text { before transplant. } \\
\text { All patients cleared DSA after } \\
\text { transplant. }\end{array}$ & $\begin{array}{l}5 \text { patients with } \mathrm{Clq} \\
\text { positive post } \\
\text { treatment had GF } \\
\text { while patients who } \\
\text { became C1q } \\
\text { negative engrafted. }\end{array}$ \\
\hline $\begin{array}{l}\text { Leffell } \\
2015^{87}\end{array}$ & $\begin{array}{l}\text { Haplo (N=13) } \\
\text { MMUD (N=2) }\end{array}$ & $\begin{array}{l}\text { Luminex } \\
\text { MFI }>1,000\end{array}$ & $\begin{array}{l}\text { Plasmapheresis + IVIg + } \\
\text { Tacrolimus }\end{array}$ & $\begin{array}{l}\text { Mean reduction of DSAs post- } \\
\text { treatment was } 64.4 \% .1 \text { patient } \\
\text { failed to reduce DSAs to the } \\
\text { level that was thought to be } \\
\text { safe for transplant. }\end{array}$ & $\begin{array}{l}14 / 14 \text { patients } \\
\text { engrafted by Day } \\
+60 \\
7 \text { pts had relapsed } \\
\text { disease }\end{array}$ \\
\hline
\end{tabular}

MFI - mean fluorescence intensity; CDC - complement-mediated cytotoxic; XM - crossmatch, FCXM - flow cytometric crossmatch, GF - graft failure; AHG-LCT - anti-human immunoglobulin lymphocytotoxicity test; NA - not available; MMUD - mismatched unrelated donor; IVIg intravenous gammaglobulin; pts - patients. 